\title{
APLIKASI KOMPRESI DATA MENGGUNAKAN METODE HUFFMAN STATIK PADA PERANGKAT MOBILE BERBASIS ANDROID
}

\author{
Heru Cahya Rustamaji, Mariani, Bambang Yuwono \\ Program Studi Teknik Informatika UPN "Veteran" Yogyakarta, \\ Jl. Babarsari no 2 Tambakbayan 55281 Yogyakarta \\ email : herucr@gmail.com, bambangy@gmail.com
}

\begin{abstract}
Efficient use of bandwidth and memory into the main focus that must be considered in the process of data exchange. More and more data is stored, the greater the size of the data. One alternative that can be implemented is to reduce the size of the (compressed) data. In addition to the process of data transmission, compression is also useful in the data storage medium in the secondary. Compression aims to reduce the amount of data used to represent the contents of a text file, image, audio, and video without reducing the quality of the original data. Compression is done by reducing the number of bits needed to store or transmit the digital media. For data compression, one algorithm has a good performance is the type of the Huffman algorithm.In this study, the Static Huffman algorithm which is one technique that is lossless data compression. Static Huffman algorithm uses frequency/probability of occurrences of a symbol in a string as input and produce output in the form of a prefix code that encodes a string using the little bits of all possible binary prefix code that may be. Static Huffman algorithm implementation is aimed to compress the data so that the compressed data size is smaller than the size of the original data. So that the compressed data can be retrieved, then the decompression process. This application was made and in the making based on Android using Eclipse and the methodology GRAPPLE (Guidlines for Rappid Application Engineering). GRAPPLE is a process modeling in software development which emphasizes the actions carried out in a number of stages, each stage will result in products that work with object-oriented form. With applications of data compression with Huffman Static method in Android -based mobile devices, the data size becomes smaller so that it can speed up the process of delivery and storage. Compression using Huffman code would be optimal if the range of the character of the information is not too much despite the high frequency of occurrence and the size of the compression results obtained that the compression of each file depending on the characteristics of the file to be compressed.
\end{abstract}

Keywords : Compression, Decompression, Static Huffman Algorithm, Lossless, Android.

Efisiensi penggunaan bandwidth dan memory menjadi satu fokus utama yang harus diperhatikan dalam proses pertukaran data. Semakin banyak data yang tersimpan maka semakin besar pula ukuran dari data tersebut.Salah satu alternatif yang dapat di implementasikan adalah memperkecil ukuran (kompresi) data tersebut. Selain pada proses pengiriman data, kompresi juga bermanfaat pada penyimpanan data di dalam media sekunder.Kompresi bertujuan untuk mengurangi jumlah data yang digunakan untuk mewakili isi file teks, gambar, audio, dan video tanpa mengurangi kualitas data aslinya. Kompresi dilakukan dengan mengurangi jumlah bit yang diperlukan untuk menyimpan atau mengirimkan media digital tersebut. Untuk kompresi data, salah satu algoritma yang memiliki performa yang baik adalah jenis algoritma Huffman.Pada penelitian ini digunakan algoritma Huffman Statik yang merupakan salah satu teknik kompresi data yang bersifat lossless. Algoritma Huffman Statik menggunakan frekuensi/probabilitas kemunculan dari simbol pada sebuah string sebagai input dan menghasilkan output berupa prefix code yang mengkodekan string menggunakan bit paling sedikit dari seluruh kemungkinan binary prefix code yang mungkin.Implementasi algoritma Huffman Statik ini bertujuan untuk mengkompresi data sehingga ukuran data hasil kompresi lebih kecil dibandingkan dengan ukuran data asli.Agar data yang terkompres dapat dilihat kembali, maka dilakukan proses dekompresi. Aplikasi ini dibuat berbasis Android dan dalam pembuatannya menggunakan Eclipse dan metodologi GRAPPLE (Guidlines for Rappid APPLication Engineering). GRAPPLE merupakan sebuah pemodelan proses dalam pengem- 
bangan software yang menekankan pada aksi-aksi yang dilakukan pada sejumlah tahapan, setiap tahap akan menghasilkan produk kerja dengan bentuk yang berorientasi objek. Dengan dibuatnya aplikasi kompresi data dengan metode Huffman Statik pada perangkat mobile berbasis android, ukuran data menjadi lebih kecil sehingga dapat mempercepat dalam proses pengiriman maupun penyimpanan. Kompresi dengan menggunakan kode Huffman akan lebih optimal jika ragam karakter dari informasi tersebut tidak terlalu banyak walaupun frekuensi kemunculannya tinggi dan ukuran hasil kompresi diperoleh bahwa pemampatan setiap file tergantung dari karakteristik file yang akan dimampatkan.

Kata Kunci : Kompresi, Dekompresi, Algoritma Huffman Statik, Lossless, Android.

\section{PENDAhULUAN}

Smartphone android yaitu handphone dengan sistem operasi yang open source.Smartphone android sekarang menjadi salah satu gadget yang menjadi pangsa pasar di Indonesia dikarenakan mudah dalam pengoperasiannya. Dengan smartphone, data atau informasi bisa diakses dimanapun dan proses pertukaran informasi akan menjadi semakin mudah. Hingga saat ini pengiriman informasi dalam bentuk teks, gambar, audio, dan video secara real-time masih mengalami kendala, yaitu besarnya ukuran data yang akan dikirimkan atau dipindahkan sehingga diperlukan kecepatan transmisi untuk proses transfer dan juga memori yang besar untuk menyimpan data atau informasi tersebut.

Masalah-masalah diatas dapat diselesaikan dengan metode kompresi. Kompresi merupakan proses untuk menghilangkan berbagai kerumitan yang tidak penting (redundansi) dari suatu informasi dengan cara memadatkan isi data file sehingga ukurannya menjadi lebih kecil dengan memaksimalkan kesederhanaannya dan tetap menjaga kualitas penggambaran dari informasi tersebut. Kompresi data menjadi sangat penting karena memperkecil kebutuhan penyimpanan data, mempercepat pengiriman data, dan menekan biaya.Teknik kompresi bisa dilakukan terhadap data teks/biner, gambar (JPEG, PNG, TIFF), audio (MP3, AAC, RMA, WMA), dan video (MPEG, H261, H263).

Pada umumnya, orang menginginkan data dengan kualitas terbaik dan kuantitas (ukuran) yang minimum.Ada dua metode utama kompresi, yaitu metode lossless dan metode lossy. Metode lossy adalah kompresi dimana terdapat data yang hilang selama proses kompresi yang mengakibatkan kualitas data yang dihasilkan jauh lebih rendah dari kualitas data asli. Sedangkan metode lossless tidak menghilangkan data selama proses kompresi terjadi, akibatnya kualitas data hasil kompresi tidak menurun. Metode ini cocok untuk mengkompresi data yang mengandung informasi penting yang tidak boleh rusak akibat kompresi. Salah satu contoh dari metode kompresi data lossless adalah algoritma Huffman, kode Huffman digunakan untuk mengurangi jumlah bit yang digunakan.

Penggunaan algoritma Huffman dalam kompresi data dimaksudkan untuk memberikan manfaat yang sangat besar dalam proses pengiriman maupun penyimpanan data pada komunikasi data, sehingga data yang telah dikompresi membutuhkan waktu pengiriman yang lebih singkat dibandingkan dengan data yang tidak terkompresi.

Melalui penelitian ini, dengan aplikasi kompresi data dengan metode Huffman Statik pada perangkat mobile berbasis android, diharapkan ukuran data pada mobile dapat lebih kecil sehingga dapat mempercepat dalam proses pengiriman maupun penyimpanan, serta hasil kompresi dan dekompresi data dapat dibagikan melalui media bluetooth maupun melalui online seperti jejaring sosial dan email.

\section{METODE PENELITIAN}

Metode perencanaan, analisis dan perancangan menggunakan metodologi Guidelines for Rapid APPlication Engineering (GRAPPLE) yaitu segmen pengumpulan kebutuhan (requirement gathering), analisis (analysis) dan perancangan (design).

\subsection{Identifikasi Sistem}

Identifikasi sistem merupakan gambaran model diagram untuk menunjukkan tata letak pada sebuah sistem secara fisik dengan menampakkan bagian-bagian perangkat lunak yang berjalan pada perangkat keras yang dibangun akan menampakkan bagian-bagian software yang berjalan pada hardware. 


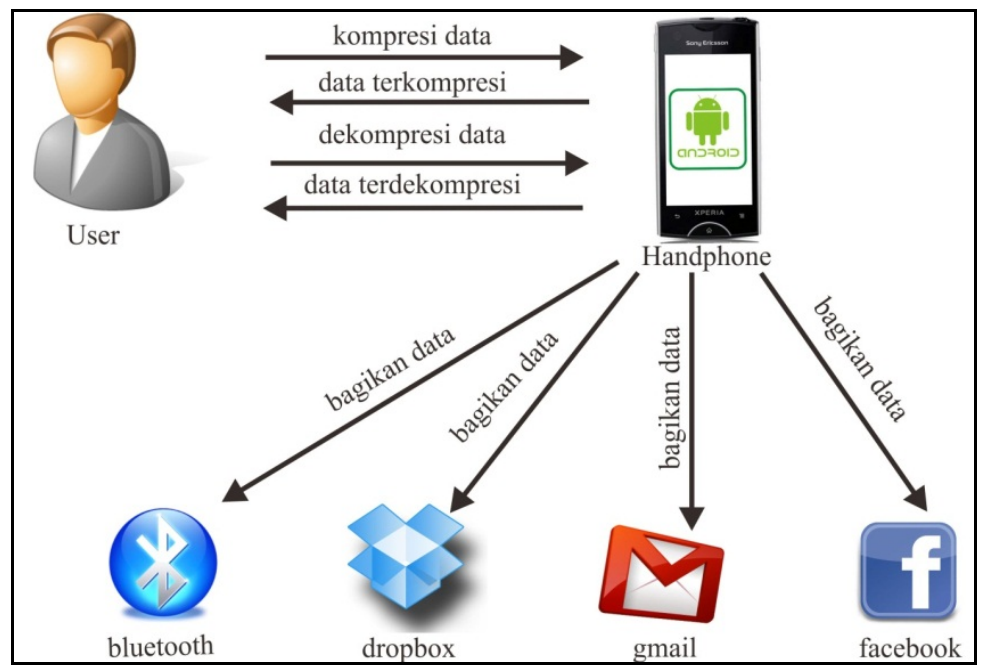

Gambar 1. Arsitektur sistem

\subsection{Diagram Use case}

Proses pengembangan sistem ini berlangsung serangkaian aktivitas yang diturunkan dari use case. Diagram use case dalam sistem yang dibangun memiliki satu aktor yaitu user (pengguna smartphoneAndroid). User dapat melakukan proses kompresi data dan proses dekompresi data, bagikan data, serta dapat juga melihat bantuan, melihat halaman tentang aplikasi, dan keluar aplikasi. Sebelum melakukan proses kompresi, user harus memilih data dari sdcard terlebih dahulu, user juga dapat menghapus data asli. Setelah proses kompresi berhasil, user dapat membagikan data hasil kompresi. Sebelum melakukan proses dekompresi, user harus memilih data bertipe .huf dari sdcard terlebih dahulu, user juga dapat menghapus data asli. Setelah proses dekompresi berhasil, user dapat membagikan data hasil dekompresi. Use case pada penjelasan di atas dapat dilihat seperti pada gambar berikut ini :

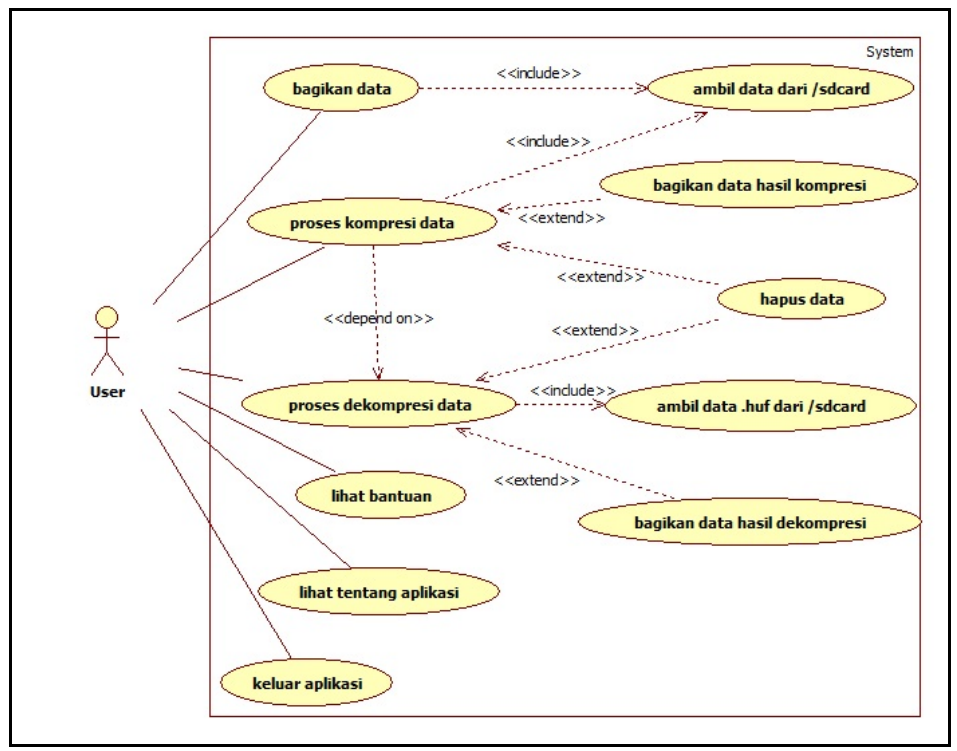

Gambar 2. Diagram use case

\subsection{Perancangan}

Rancangan struktur menu merupakan gambaran menu apa saja yang terdapat dalam aplikasi kompresi data yang disusun secara hirarki. Dalam sistem ini terdapat 3 menu utama yaitu kompresi, dekompresi, dan bagikan. Untuk menu kompresi, data hasil proses kompresi dapat dibagikan melalui bluetooth maupun melalui media online seperti jejaring sosial, emaildan juga menu dekompresi, data hasil proses dekompresi juga dapat dibagikan melalui bluetooth 
maupun melalui media online seperti jejaring sosial dan email. Struktur menu dapat dilihat pada gambarberikut ini :

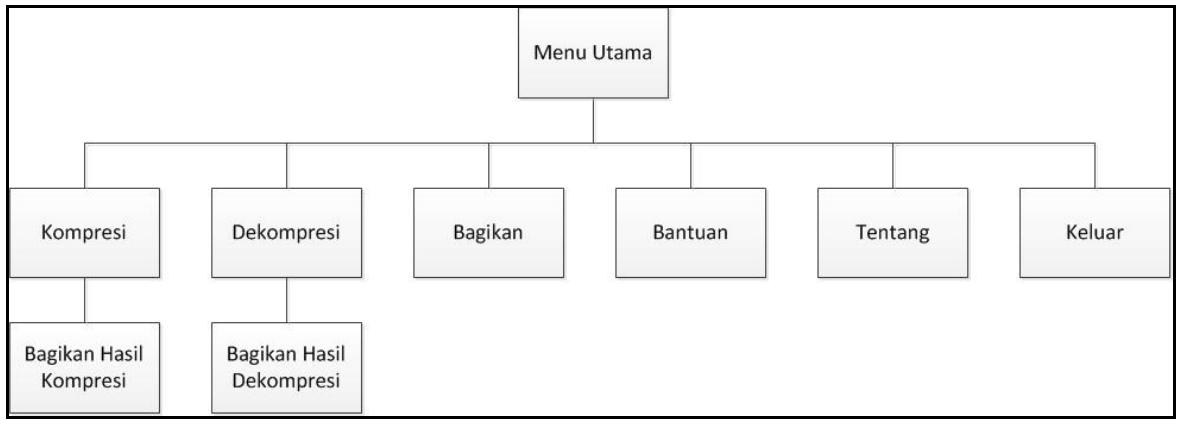

Gambar 3. Rancangan struktur menu

\section{HASIL DAN PEMBAHASAN}

Dalam segmen pembahasan ini akan terlihat aplikasi yang dibuat sesuai dengan analisis dan perancangan yang sebelumnya telah dibuat.

\subsection{Perangkat Lunak Yang Digunakan}

Dalam membuat AplikasiKompresi Data Menggunakan Metode Huffman Statik Pada Perangkat Mobile Berbasis Android diperlukan beberapa perangkat lunak (software) untuk membantu pengerjaan aplikasi. Perangkat lunak yang digunakan didalam pembuatan aplikasi dapat dilihat pada tabel berikut :

Tabel 1. Tabel Kebutuhan Perangkat Lunak (software)

\begin{tabular}{|c|l|l|}
\hline No & \multicolumn{1}{|c|}{ Perangkat Lunak } & \multicolumn{1}{c|}{ Keterangan } \\
\hline 1 & Windows 7 Home Premium & Sistem Operasi \\
\hline 2 & ADT eclipse & Perangkat lunak untuk design interface dan code editor \\
\hline 3 & Android SDK & $\begin{array}{l}\text { Perangkat lunak untuk proses debugging program dari } \\
\text { code editor }\end{array}$ \\
\hline 4 & StarUML & Perangkat lunak untuk desain pemodelan UML \\
\hline
\end{tabular}

\subsection{Perangkat Keras Yang Digunakan}

Dalam membuat AplikasiKompresi Data Menggunakan Metode Huffman Statik Pada Perangkat Mobile Berbasis Android diperlukan beberapa perangkat keras (hardware) untuk membantu pengerjaan aplikasi. Perangkat keras yang digunakan didalam pembuatan aplikasi dapat dilihat pada tabel berikut :

Tabel 2. Tabel Kebutuhan Perangkat Keras (hardware)

\begin{tabular}{|c|l|l|}
\hline No & \multicolumn{1}{|c|}{ Perangkat Lunak } & \multicolumn{1}{c|}{ Keterangan } \\
\hline 1 & Laptop & HP Pavilion dv3 Notebook PC \\
\hline & Processor & Intel(R) Core(TM) i3 CPU M 330 @ 2.13GHz \\
\hline & Memory & 2024 MB DDR3 RAM \\
\hline & VGA & ATI Radeon \\
\hline & Harddisk & 320 GB SATA \\
\hline 2 & Handphone & Sony Ericsson Xperia Ray \\
\hline
\end{tabular}

Berikut implementasi dari aplikasi : 


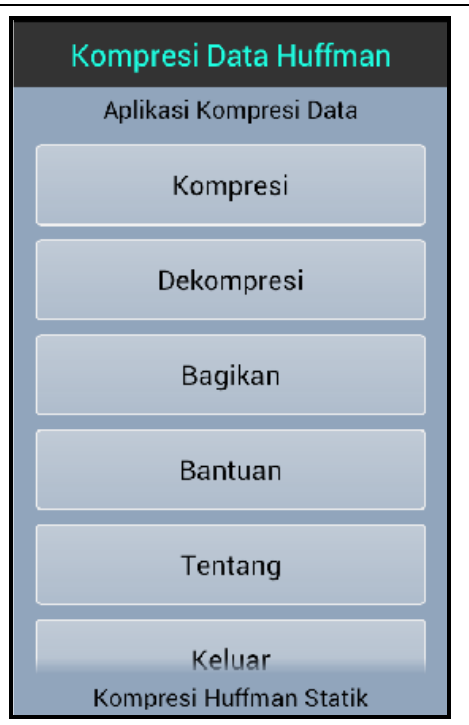

\section{Gambar 4. Halaman menu utama}

Halaman menu utama adalah halaman yang pertama kali muncul saat user menjalankan aplikasi. Halaman ini menampilkan menu kompresi, dekompresi, bagikan, bantuan, tentang, dan keluar.

Ketika memilih menu Kompresi pada menu utama maka akan muncul tampilan seperti berikut.

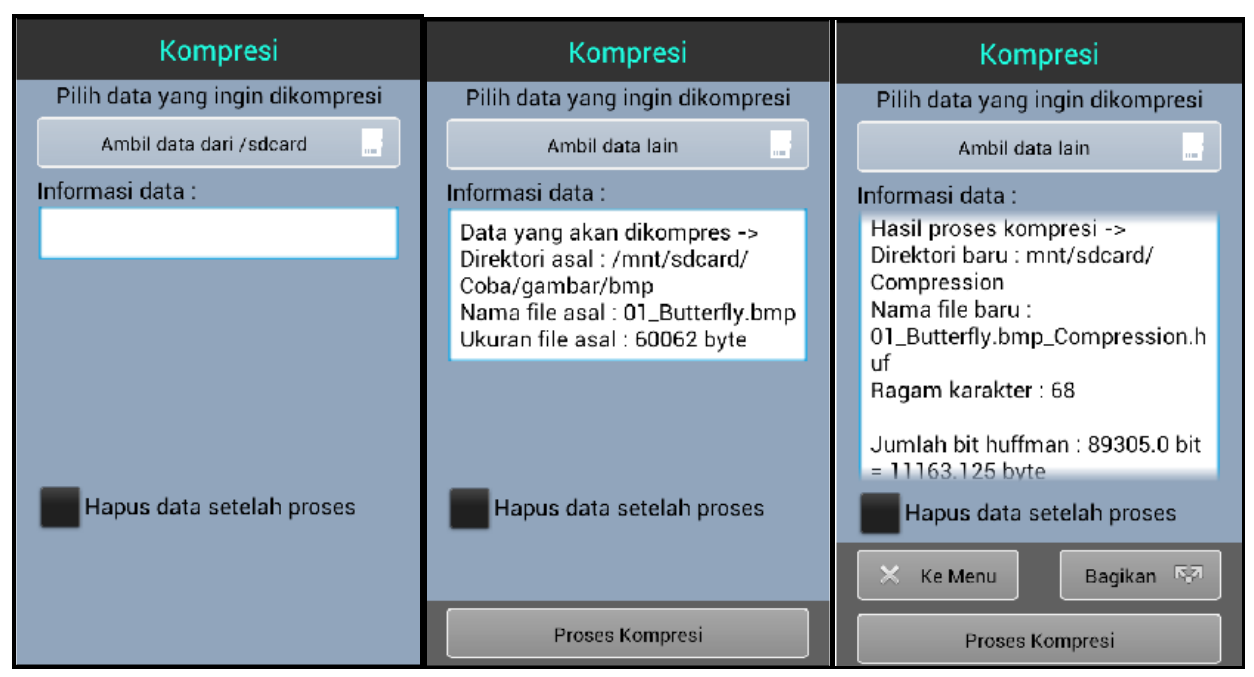

Gambar 5. Halaman Kompresi

Kompresi merupakan halaman untuk melakukan proses kompresi data. Disini user selaku pengguna aplikasi memilih data dari sdcard yang akan digunakan untuk proses kompresi. Setelah data dipilih, user mengetahui tentang informasi datanya. Data yang berisi data asli bisa dihapus oleh user dari media penyimpanan dan sebagai gantinya yang disimpan adalah data yang telah terkompresi dengan mencentang hapus data setelah proses. Setelah data berhasil dikompres, user dapat membagikan data melalui bluetooth maupun melalui media online seperti jejaring sosial, email, atau kembali kemenu utama, atau ambil data lain dari sdcard.

Ketika memilih menu Dekompresi pada menu utama maka akan muncul tampilan seperti berikut. 


\begin{tabular}{|c|c|c|}
\hline Dekompresi & Dekompresi & Dekompresi \\
\hline Pilih data yang ingin didekompresi & Pilih data yang ingin didekompresi & Pilih data yang ingin didekompresi \\
\hline Ambil data *.huf dari /sdcard & Ambil data $\cdot$ huf lain & Ambil data $\cdot$ huf lain \\
\hline Informasi data : & Informasi data: & Informasi data : \\
\hline & $\begin{array}{l}\text { Data yang akan didekompres -> } \\
\text { Direktori asal : /mnt/sdcard/ } \\
\text { Compression } \\
\text { Nama file asal: } \\
\text { 01_Butterfly.bmp_Compression.h } \\
\text { uf } \\
\text { Ukuran file asal : } 11366 \text { byte }\end{array}$ & $\begin{array}{l}\text { Hasil proses dekompresi -> } \\
\text { Direktori baru : mnt/sdcard/ } \\
\text { Compression } \\
\text { Ukuran file hasil dekompresi : } \\
60062 \text { byte } \\
\text { Ragam karakter : } 68 \\
\text { Waktu proses : } 6.949157717 \\
\text { detik }\end{array}$ \\
\hline \multirow[t]{3}{*}{ Hapus data setelah proses } & \multirow[t]{2}{*}{ Hapus data setelah proses } & Hapus data setelah proses \\
\hline & & X Ke Menu Bagikan \\
\hline & Proses Dekompresi & Proses Dekompresi \\
\hline
\end{tabular}

\section{Gambar 6. Halaman Dekompresi}

Dekompresi adalah halaman untuk melakukan proses dekompresi data. Disini user selaku pengguna aplikasi hanya dapat memilih data yang bertipe .huf dari sdcard yang akan digunakan untuk proses dekompresi. Setelah data dipilih, user mengetahui tentang informasi datanya. Data yang berisi data asli bisa dihapus oleh user dari media penyimpanan dan sebagai gantinya yang disimpan adalah data yang telah terdekompresi dengan mencentang hapus data setelah proses. Setelah data berhasil didekompres, user dapat membagikan data melalui melalui bluetooth maupun melalui media online seperti jejaring sosial, emailatau kembali kemenu utama, atau ambil data .huf lain dari sdcard.

Ketika memilih menu Bagikan maka akan muncul tampilan seperti berikut.

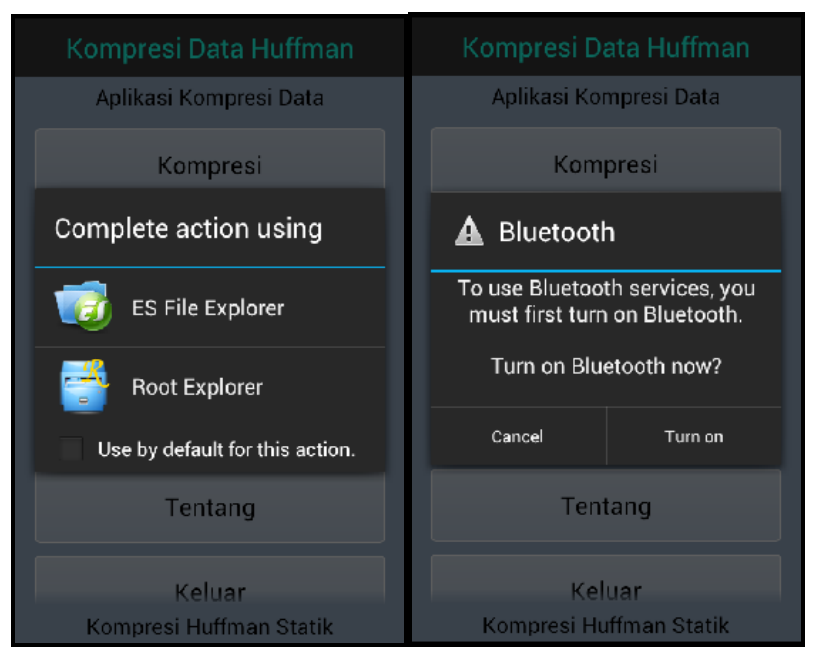

\section{Gambar 7. Halaman Bagikan}

Bagikan adalah menu untuk melakukan proses pengiriman data hasil proses kompresi dan dekompresi. User memilih menu Bagikan pada Menu Utama yang mana aplikasi akan merespon untuk menampilkan show explorer.User dapat memilih data yang akan dibagikan dan memilih media pengiriman.

Ketika memilih menu Bantuan maka akan muncul tampilan seperti berikut. 


\begin{tabular}{|c|c|}
\hline Bantuan & Bantuan \\
\hline $\begin{array}{l}\text { Compression } \\
\text { Aplikasi ini digunakan untuk } \\
\text { mengkompresi data dengan } \\
\text { metode kompresi Huffman } \\
\text { Statik. } \\
\text { Aplikasi ini terdiri dari } 6 \text { menu } \\
\text { yaitu: } \\
\text { 1. Kompresi } \\
\text { Menu ini digunakan untuk mengkompresi } \\
\text { data sehingga ukuran data menjadi lebih kecil } \\
\text { dan tidak dapat dibaca atau dibuka. Di menu } \\
\text { ini anda harus memilih data terlebihi dahulu } \\
\text { dengan menekan tombol ambil data dari } \\
\text { sdcard. Setelah itu anda diperkenankan } \\
\text { untuk menghapus data awal yang dikompres, } \\
\text { lalu tekan tombol Proses Kompresi untuk } \\
\text { memulai proses kompresi. Setelah data } \\
\text { berhasil dikompres, anda diperkenankan } \\
\text { untuk membagikan data tersebut atau } \\
\text { Kompresi Huffman Statik }\end{array}$ & $\begin{array}{l}\text { Compression } \\
\text { 2. Dekompresi } \\
\text { Menu ini digunakan untuk mendekompresi } \\
\text { data sehingga data anda kembali ke ukuran } \\
\text { semula dan data dapat dibaca atau dibuka. } \\
\text { Untuk mendekompresi data, anda harus } \\
\text { memilih data yang akan didekompresi } \\
\text { dengan menekan tombol ambil data *huf } \\
\text { dari /sdcard. Setelah itu anda diperkenankan } \\
\text { untuk menghapus data awal yang } \\
\text { didekompres, lalu tekan tornbal Proses } \\
\text { Dekompresi untuk memulai proses } \\
\text { dekompresi. Setelah data berhasil } \\
\text { didekompres, anda diperkenankan untuk } \\
\text { membagikan data tersebut atau kembali ke } \\
\text { menu awal. } \\
\text { 3. Bagikan } \\
\text { Menu ini digunakan untuk membagikan data. } \\
\text { 4. Bantuan } \\
\text { Kompresi Huffman Statik }\end{array}$ \\
\hline
\end{tabular}

\section{Gambar 8. Halaman Bantuan}

Bantuan adalah halaman untuk melihat bantuan. Pada halaman ini terdapatteks yang berisi panduan dalam menggunakan aplikasi, sehingga user dapat melihat tentang cara menggunakan aplikasi kompresi data ini.

Ketika memilih menu Tentang maka akan muncul tampilan seperti berikut.

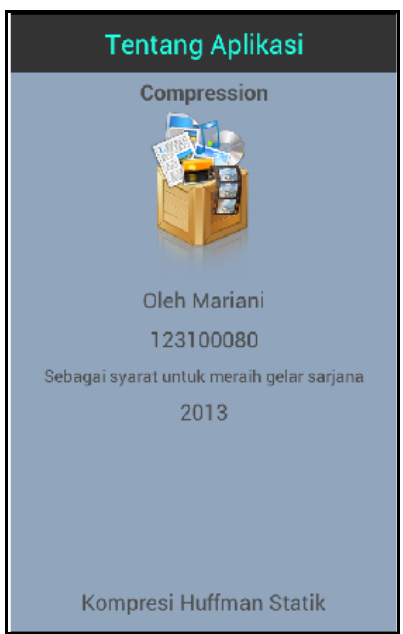

\section{Gambar 9. Halaman Tentang Aplikasi}

Tentang aplikasi adalah halaman untuk melihat tentang aplikasi. Di sini, user dapat melihat keterangan tentang aplikasi beserta gambar logo aplikasi kompresi data dan si pembuatnya.

Ketika memilih menu Keluar maka akan muncul tampilan seperti berikut. 


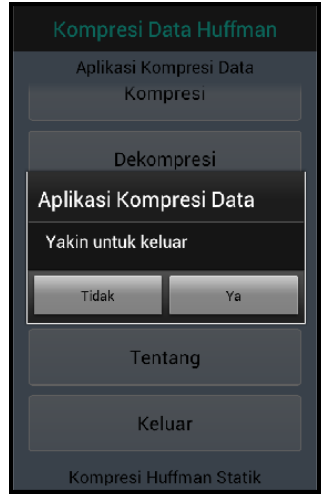

\section{Gambar 10. Halaman Keluar}

Keluaradalah menu untuk keluar dari aplikasi. User memilih menu Keluar pada Menu Utama yang mana aplikasi akan merespon untuk memunculkan alertdialog dengan memberikan pertanyaan kepada user apakah yakin untuk keluar dari aplikasi, user tekan tombol ya atau tidak, jika ya maka akan keluar dari aplikasi, dan jika tidak maka akan kembali ke menu.

Tahap pengujian yang dilakukan adalah dengan uji coba proses kompresi dan dekompresi pada berbagai macam data teks, gambar, audio, dan video.

Tabel 3. Tabel Pengujian Kompresi pada beberapa file

\begin{tabular}{|c|c|c|c|c|c|c|c|c|c|c|}
\hline \multirow[t]{2}{*}{ No } & \multicolumn{2}{|c|}{$\begin{array}{l}\text { Data sebelum } \\
\text { dikompresi }\end{array}$} & \multicolumn{8}{|c|}{ Hasil proses kompresi } \\
\hline & $\begin{array}{c}\text { Nama } \\
\text { file }\end{array}$ & $\begin{array}{c}\text { Ukuran } \\
\text { file } \\
\text { (byte) }\end{array}$ & $\begin{array}{l}\text { Ragam } \\
\text { karakter }\end{array}$ & $\begin{array}{l}\text { Jumlah } \\
\text { Bit } \\
\text { Huffman } \\
\text { (byte) }\end{array}$ & $\begin{array}{l}\text { Entropi } \\
\text { per } \\
\text { karakter } \\
\text { (bit) }\end{array}$ & $\begin{array}{c}\text { Jumlah } \\
\text { Bit } \\
\text { Entropi } \\
\text { (byte) }\end{array}$ & $\begin{array}{l}\text { Ukuran } \\
\text { file } \\
\text { kompresi } \\
\text { (byte) }\end{array}$ & $\begin{array}{c}\text { Rasio } \\
\text { kompresi } \\
\text { dari file } \\
(\%)\end{array}$ & $\begin{array}{c}\text { Rasio } \\
\text { kompresi } \\
\text { bit data } \\
(\%)\end{array}$ & $\begin{array}{l}\text { Waktu } \\
\text { proses } \\
\text { (detik) }\end{array}$ \\
\hline 1. & $\begin{array}{l}04 \text { Bir } \\
\text { d.bmp } \\
\end{array}$ & 60062 & 71 & 10212,5 & 0.8326 & 6251,54 & 10430 & 82,63 & 82,99 & 3,21 \\
\hline 2. & $\begin{array}{l}\text { dokum } \\
\text { en.txt }\end{array}$ & 3853 & 40 & 2050,25 & 4,227 & 2035,83 & 2160 & 43,93 & 46,788 & 0,97 \\
\hline 3. & $\begin{array}{l}\text { mdm01 } \\
\text { 1.mid }\end{array}$ & 15557 & 174 & $\begin{array}{l}11429,1 \\
2\end{array}$ & 5,84 & $\begin{array}{l}11375,5 \\
7\end{array}$ & 11922 & 23,36 & 26,53 & 3,58 \\
\hline 4. & $\begin{array}{l}\text { happy_- } \\
\text { bday.3 } \\
\text { gp }\end{array}$ & 178810 & 256 & $\begin{array}{l}160324, \\
6\end{array}$ & 7,13 & 159436 & 161015 & 9,95 & 10,33 & 44,30 \\
\hline
\end{tabular}

Tabel 4. Tabel Pengujian Dekompresi pada beberapa file

\begin{tabular}{|c|c|c|c|c|c|}
\hline No & \multicolumn{2}{|l|}{ Data sebelum dikompresi } & \multicolumn{3}{|c|}{ Hasil proses kompresi } \\
\hline & Nama file & $\begin{array}{l}\text { Ukuran } \\
\text { file } \\
\text { (byte) }\end{array}$ & $\begin{array}{l}\text { Ragam } \\
\text { karakter }\end{array}$ & $\begin{array}{l}\text { Ukuran file } \\
\text { kompresi (byte) + } \\
\text { nama file }\end{array}$ & $\begin{array}{l}\text { Waktu proses } \\
\text { (detik) }\end{array}$ \\
\hline 1. & 04_Bird.bmp_Compression.huf & 10430 & 71 & 04_Bird.bmp & 4,30067663 \\
\hline 2. & dokumen.txt_Compression.huf & 2160 & 40 & $\begin{array}{l}3853 \\
\text { dokumen.txt }\end{array}$ & 1,108825684 \\
\hline 3. & mdm011.mid_Compression.huf & 11922 & 174 & $\begin{array}{l}15557 \\
\mathrm{mdm} 011 . \mathrm{mid}\end{array}$ & 5,586853032 \\
\hline 4. & happy_bday.3gp_Compression.huf & 161015 & 256 & $\begin{array}{l}178810 \\
\text { happy_bday.3gp }\end{array}$ & 55,101989867 \\
\hline
\end{tabular}




\section{KESIMPULAN}

Berdasarkan hasil analisis, perancangan, dan implementasi dapat disimpulkan bahwa telah berhasil dibuat Aplikasi Kompresi Data menggunakan metode Huffman Statik pada perangkat Mobile berbasis Android.

Diperoleh hasil pengujian sistem adalah sebagai berikut:

1. Kompresi dengan menggunakan kode Huffman akan lebih optimal jika ragam karakter dari informasi tersebut tidak terlalu banyak walaupun frekuensi kemunculannya tinggi, karena pohon Huffman yang akan terbentuk tidak terlalu panjang sehingga kode Huffman yang mewakili karakter tersebut menjadi lebih singkat. Pohon Huffman membutuhkan minimal 2 ragam karakter yang mana 2 ragam karakter itu menjadi node/cabang dan penjumlahan dari 2 ragam karakter tersebut membentuk node baru yang dijadikan sebagai akar pada pembuatan pohon Huffman.

2. Berdasarkan hasil analisis terhadap ukuran hasil kompresi diperoleh bahwa pemampatan setiap file tergantung dari karakteristik file yang akan dimampatkan. Sedangkan analisis terhadap kecepatan pemampatan file diperoleh bahwa jika ukuran file semakin besar maka semakin lama waktu yang dibutuhkan untuk melakukan proses kompresi.

3. Aplikasi kompresi ini baik digunakan pada file gambar berekstensi *.bmp, dan *.gif, pada file teks berekstensi *.doc, *.docx, *.rtf, dan *.txt, file audio berekstensi *.ogg, ${ }^{*}$.mid, *.mp3, dan *.wav, sedangkan pada file video berekstensi *.3gp, *.wmv, dan *.flv. Jika dilihat dari codeword/bit Huffman hasil kompresi, file seperti *.jpg, *.png, dan *.pdf sebenarnya telah berhasil dikompres namun dengan rasio kompresi yang kecil. File hasil kompresi tidak hanya menyimpan codeword/bit Huffman, tetapi juga menyimpan Huffman Signature dan pohon Huffman yang menyebabkan file tersebut membesar.

\section{DAFTAR PUSTAKA}

Adisantoso, J., Sulistio, D.D., Silalahi, B.P., 2004, Kompresi Data Menggunakan Algoritma Huffman, http://journal.uii.ac.id/index.php/Snati/article/viewFile/1822/1601, Diakses pada tanggal 23 September 2013.

Adityo, W., 2008, Penggunaan Kode Huffman dan Kode Aritmatik pada Entropy Coding, www.informatika.org/ rinaldi/Matdis/2007-2008/. Makalah/MakalahIF2153-0708-105.pdf, Diakses pada tanggal 23 September 2013.

Brookshear, J. Glenn, 2003,Computer Science Suatu pengantar, Jilid 7, Terjemahan Irzam Hardiansyah, Jakarta: Erlangga.

Citra, Anastasya, 2010,Aplikasi Kompresi Sms Menggunakan Kode Huffman pada Mobile Phone Berbasis JavaTM, Departemen Teknik Elektro Fakultas Teknik Universitas Sumatera Utara.

Fauzi, Rahmad, 2010,Analisis Beberapa Teknik Coding,http://library.usu.id/download/ft/elekrorahmad\%20fauzi.pdf, Diakses pada tanggal 23 September 2013.

Gonzalez, Rafael, 1992,Digital Image Processing, USA: Addison-Wesley Publishing Co.

Jogiyanto, 2005, Analisis dan desain Sistem Informasi, Penerbit: ANDI, Yogyakarta.

Johnsonbaugh, Richard, 1998, Matematika Diskrit, Jilid 2, Jakarta: Prenhallindo.

Jong, Jek Siang, 2002, Matematika Diskrit dan Aplikasinya pada IImu Komputer, Yogyakarta: Andi.

Kadir, A., 2002, Pengenalan Sistem Informasi, Andi, Yogyakarta.

Kristanto, A., 2003, Struktur Data Dengan C++. Edisi Pertama, Yogyakarta: Graha Ilmu.

Munir, Rinaldi., 2004,Pengolahan Citra Digital dengan Pendekatan Algoritmik. Bandung: Informatika.

Pearlman, William.A., 1997, The Set Partitioning in Hierarchical Trees (SPIHT) Algorithm, Rensselaer Polytechnic Institute.

Pu, I. M., 2006, Fundamental Data Compression,Oxford : Elsevier.

Risyana, 2009, Pengertian Data, Informasi, Knowledge, dan Sistem, http://risyana.wordpress.com/2009/11/14/pengertian-data-informasi-knowledge-dansistem/, Diakses pada tanggal 23 September 2013.

Romdoni, A., 2010, Pengertian Aplikasi Mobile, http://agusbarupunyablog.blogspot.com, Diakses pada tanggal 23 September 2013.

Salomon, D., 2007, Data Compression The Complete Reference, 4th Edition, Northridge: Spinger. 
Salomon, David dan Giovanni, 2010,Handbook of Data Compression,Fifth Edition,London : Springer - Verlag Limited.

Sayood, K., 2003, Lossless Compression Handbook, 1st Edition, San Diego: Elsevier.

Sayood, K., 2005, Introduction to Data Compression. 3rd Edition, San Diego: Elsevier.

Schmuller, Joseph, 1999, Teach Yourself UML in 24 Hours, Indianapolis: Sams Publishing.

Sedgewick, R., 2002, Algoritms in Java. 3rd Edition, Pearson Education.

Setiawan, Wawan. dan Munir, 2006, Pengantar Teknologi Informasi: Basis Data, Bandung: Universitas Pendidikan Indonesia.

Sharma, M., 2010,Compression using Huffman coding,IJCSNS International Journal of Computer Science and Network Security.10(2).131-141.

ST, Mulyadi, 2010, Membuat Aplikasi untuk Android, Multimedia Center Publishing, Yogyakarta.

Sudewa, Ida Bagus Adi, 2003,Mengenal Character Set,www.ilmukomputer.com, Diakses pada tanggal 23 September 2013.

Suhendar A. dan Gunadi H., 2002, Visual Modeling Menggunakan UML dan Rational Rose, Informatika, Bandung.

Sulistyanto, Hernawan,2006, Kompresi Data Lossless dengan Metode Lempel-Zip, Surakarta: Jurnal Teknik Elektro dan Komputer EMITOR, Bandung.

Sutoyo, T. dkk, 2009, Teori Pengolahan Citra Digital, Penerbit Andi, Yogyakarta.

Timotius, Triputra, 2010, Perbandingan Kompresi Data Dengan Algoritma Huffman Statik dan Adaptif,http://informatika.stei.itb.ac.id/ rinaldi.munir/Matdis/20102011/Makalah2010/MakalahStrukdis2010-008.pdf, Diakses pada tanggal 23 September 2013.

Vercellis, Carlo, 2009,Business intelligence : data mining and optimization for decision making, Chichester: John Wiley \& Sons.

Wahidah, Wahyu L., 2008, Aplikasi Perbandingan Metode Huffman dan Run Length Encoding Pada Kompresi Citra Digital, Yogyakarta : Universitas Pembangunan Nasional Veteran Yogyakarta. , http://st0lenc0des.googlepages.com, Diakses pada tanggal 23 September 2013. http://www.mcscv.com/, Diakses pada tanggal 23 September 2013.

2013 ,ASCII, Wikipedia, http://id.wikipedia.org/wiki/ASCII, Diakses pada tanggal 23 September 